\title{
Productivity and seedling recruitment of naturalised annual clovers versus sown clovers Trifolium repens and Trifolium subterraneum
}

\author{
T.M.R. MAXWELL ${ }^{1}$, J.L. MOIR ${ }^{2}$ and G.R. EDWARDS ${ }^{1}$ \\ ${ }^{1}$ Department of Agricultural Sciences, and ${ }^{2}$ Department of Soil and Physical Sciences, PO Box 85084, \\ Lincoln University, Lincoln 7647, Christchurch \\ tom.maxwell@lincoln.ac.nz
}

\begin{abstract}
Naturalised annual clover (NAC) species (suckling clover, cluster clover, striated clover, and haresfoot clover) are commonly present to locally abundant in summer dry hill and high country areas where white and subterranean (sub) clover abundance is limited. This field trial investigated NAC species dry matter production and seedling regeneration compared to white and sub clover. Autumn seedling recruitment was measured in response to low $(75 \mathrm{~kg} / \mathrm{ha})$ or high $(200 \mathrm{~kg} /$ ha) superphosphate (SP) application. Over two growing seasons, NAC species contributed $>90 \%$ to pasture legume content while white and sub clover contributed $<10 \%$. Striated, suckling, and cluster clovers showed greater recruitment under low SP with 996, 978, and 227 seedlings $/ \mathrm{m}^{2}$ respectively compared to high SP with 635,466 , and 123 seedlings $/ \mathrm{m}^{2}$ respectively. Collectively, NAC species were superior to white and sub clover on north-facing slopes. Spreading NAC species seed via livestock dung dispersal and aerial broadcasting would further increase their contribution to total pasture DM and nitrogen input.
\end{abstract}

Keywords: annual legumes, striated clover, Trifolium striatum, cluster clover, T. glomeratum, suckling clover, T. dubium, white clover, subterranean clover, superphosphate, phosphorus, sulphur, seedling recruitment, hill and high country.

\section{Introduction}

The opportunity exists to increase the productivity of South Island hill and high country grazing land of lower-middle altitude (300-900 m a.s.l.). Retirement of higher altitude land ( $>900 \mathrm{~m}$ a.s.l.) to conservation and recreation resulting from land tenure review (O'Connor 2003; Gillespie et al. 2006) has reduced grazing areas available for high country farming. Dairy cattle expansion into lowland areas has reduced the area of pasture available for intensive finishing of sheep and beef cattle reared on hill and high country (Moot et al. 2009). Nitrogen (N) inputs sourced primarily from sward legumes and associated biological $\mathrm{N}$ fixation (Haynes \& Williams 1993) drives productivity of remaining hill and high country pasture in summer dry (500-800 $\mathrm{mm}$ rainfall per annum) areas.

Increasing the abundance of legumes within grazing lands has been the keystone of pastoral improvement in New Zealand hill and high country, as low available $\mathrm{N}$ of most hill and high country soils (White 1990) is the primary limitation to pasture productivity. Traditional pasture improvement in upland New Zealand areas involved broadcast oversowing with legume species such as white clover (Trifolium repens L.) and subterranean (sub) clover (Trifolium subterraneum L.) in combination with aerial topdressing of phosphorus (P) and sulphur (S) fertiliser (Bowatte et al. 2006). However, long term abundance of white and sub clover is limited. Poor establishment on summer dry slopes with annual soil moisture deficits limit production, survival, and thus persistence of white clover (Knowles et al. 2003; Power et al. 2006) which phenologically exhibits optimum growth and stolon propagation during summer when soil moisture stress is greatest. Additionally, white clover is as a highly productive legume species adapted to high soil fertility conditions (high P, S and pH levels) for optimum growth (Haynes \& Williams 1993; Moir et al. 1997). Low available $P$ and $\mathrm{S}$ and low $\mathrm{pH}(4.5-5.5)$ levels are the main soil fertility limitations to pasture legume productivity in hill and high country areas (Edmeades et al. 1984; Moir \& Moot 2010). Achieving greater legume abundance necessitates $\mathrm{P}, \mathrm{S}$ and lime $\left(\mathrm{CaCO}_{3}\right)$ application to alleviate soil fertility constraints.

New Zealand's herbaceous flora contains a suite of naturalised annual legumes. Haresfoot clover (Trifolium arvense L.), suckling clover ( $T$. dubium Sibth), cluster clover (T. glomeratum L.) and striated clover (T. striatum L.) are widely distributed across South Island hill and high country (Boswell et al. 2003; Rose \& Frampton 2007; Maxwell et al. 2010). Originating from Asia Minor, the Mediterranean, North Africa and Western Europe (Webb et al. 1988) they are commonly present to locally abundant in summer dry zones, especially on hillsides of northerly-facing (sunny) aspects (Boswell et al. 2003; Power et al. 2006; Maxwell et al. 2010). Increasing the abundance 
of these naturalised annual clover (NAC) species may elevate overall legume abundance of hill and high country grazed pasture. However, little is known about their biomass accumulation, especially in comparison to white and sub clover in hill and high country environments. The relationship between NAC seedling regeneration and superphosphate fertiliser application has yet to be studied in a New Zealand hill or high country context. Recent climate-controlled studies by Maxwell et al. $(2012,2013)$ showed little dry matter (DM) response by NAC species to phosphate (P), sulphate (S), and lime addition. More field-based agronomic information about NAC species will benefit sustainable livestock production practice in low-input, hill and high country dryland areas.

At a summer-dry hill country site on an extensive sheep and beef high country station in Central Otago, a field trial was conducted with the objective of quantifying annual DM production of NAC species compared to white and sub clover, and measuring autumn seedling recruitment in relation to low and high superphosphate (P and S) application.

\section{Methods}

Study Site

The field trial was conducted at Lincoln University's Mt Grand Station, 2131 ha of hill and high country farmland located near Lake Hawea, Central Otago (lat $44^{\circ} 38^{\prime} 01.93^{\prime \prime} \mathrm{S}$; long $169^{\circ} 19^{\prime} 42.89^{\prime \prime}$ E) with altitude ranging from 380 to $1400 \mathrm{~m}$ a.s.l. The mid-altitude trial site (700 m a.s.1.) was situated on a north-facing (sunny aspect) hillside of moderate to steep slope $\left(20-30^{\circ}\right)$ within a 65 ha hill block of Arrow steepland soil (Pallic/Yellow Grey Earth; USDA classification Fragiudalf) with schist and loess parent material (Duncan et al. 1997; Power et al. 2006). Soil pH was

Table 1 Pasture biomass and botanical components of the mid-altitude $(700 \mathrm{~m}$ a.s.l.) summer dry high country field site at Broadspur hill block, Mt Grand, Central Otago, New Zealand, from October 2008 to May 2010. ${ }^{* \star *},{ }^{* \star}$ and * indicate significant differences at $\mathrm{P} \leq 0.001, \mathrm{P} \leq 0.01$ and $\mathrm{P} \leq 0.05$ respectively. Different letters denote means that are significantly different at the $5 \%$ level.

\begin{tabular}{|c|c|c|c|c|}
\hline \multirow[b]{2}{*}{ Botanical components } & \multicolumn{2}{|c|}{ Biomass (\%) } & \multicolumn{2}{|c|}{ Biomass (kg DM $\left.\cdot \mathrm{ha}^{-1}\right)$} \\
\hline & Year 1 & Year 2 & Year 1 & Year 2 \\
\hline \multicolumn{5}{|l|}{ Naturalised annual clovers } \\
\hline Haresfoot $T$. arvense & $0.4 \mathrm{a}$ & $0.01 \mathrm{a}$ & $12.6 \mathrm{a}$ & $0.3 \mathrm{a}$ \\
\hline Suckling T. dubium & $5.7 \mathrm{~b}$ & $0.1 \mathrm{a}$ & $125.7 b$ & $1.8 \mathrm{a}$ \\
\hline Cluster T. glomeratum & $7.2 \mathrm{~b}$ & $0.1 \mathrm{a}$ & $186.7 \mathrm{c}$ & $1.9 \mathrm{a}$ \\
\hline Striated $T$. striatum & $14.4 \mathrm{c}$ & $1.7 \mathrm{~b}$ & $343 d$ & $46.6 \mathrm{~b}$ \\
\hline \multicolumn{5}{|l|}{ Historically oversown clovers } \\
\hline White $T$. repens & $0.4 \mathrm{a}$ & $0.2 \mathrm{a}$ & $12.2 \mathrm{a}$ & $6.8 \mathrm{a}$ \\
\hline Sub T. subterraneum & $0.4 \mathrm{a}$ & $0.04 \mathrm{a}$ & $8.9 \mathrm{a}$ & $0.7 \mathrm{a}$ \\
\hline Total clover & 28.4 & 2.2 & 689.1 & 58.1 \\
\hline Significance & $* \star *$ & $* \star *$ & $* \star *$ & *** \\
\hline Grasses $^{1}$ & $35.5 b$ & $27.3 b$ & $888 \mathrm{~b}$ & $730 \mathrm{~b}$ \\
\hline Weeds $^{2}$ & $2.6 \mathrm{a}$ & $3.2 \mathrm{a}$ & $62 \mathrm{a}$ & $65 \mathrm{a}$ \\
\hline Herbs $^{2}$ & $0.1 \mathrm{a}$ & $0.8 \mathrm{a}$ & $2 \mathrm{a}$ & $11 \mathrm{a}$ \\
\hline Dead & $33.4 \mathrm{~b}$ & $66.6 \mathrm{c}$ & $859 b$ & $1570 \mathrm{c}$ \\
\hline Significance & 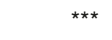 & 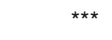 & 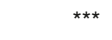 & *** \\
\hline Naturalised annual clovers & $27.6 \mathrm{a}$ & $1.9 \mathrm{a}$ & 668 a & $51 \mathrm{a}$ \\
\hline Grasses & $35.5 b$ & $27.3 b$ & $888 b$ & $730 \mathrm{~b}$ \\
\hline Dead & $33.4 a b$ & $66.6 \mathrm{c}$ & $859 b$ & $1570 \mathrm{c}$ \\
\hline Significance & ** & 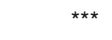 & ** & 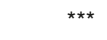 \\
\hline Mean Annual Pasture biomass & & & 2500 & 2433 \\
\hline
\end{tabular}

1 Grass species present: Browntop Agrostis capillaris L., Kentucky bluegrass Poa pratensis L., Annual poa Poa annua L., Sweet vernal Anoxanthum odoratum L., Tall oat grass Arrhenatherum elatius L., Blue wheat grass Elymus spp., Danthonia grasses Rytidosperma spp., Perennial ryegrass Lolium perenne L., Cocksfoot Dactylis glomerata, Downy brome Bromus tectorum L., Ripgut brome Bromus diandrus Roth, Needle grass Austrostipa nodosa

2 Weed and herb species present: Mouse-ear hawkweed Hieraceum pilosella, Hawksbeard Crepis capillaris L., Storksbill Erodium cicutarium, Sheep's sorrel Rumex acetosella $L$. 


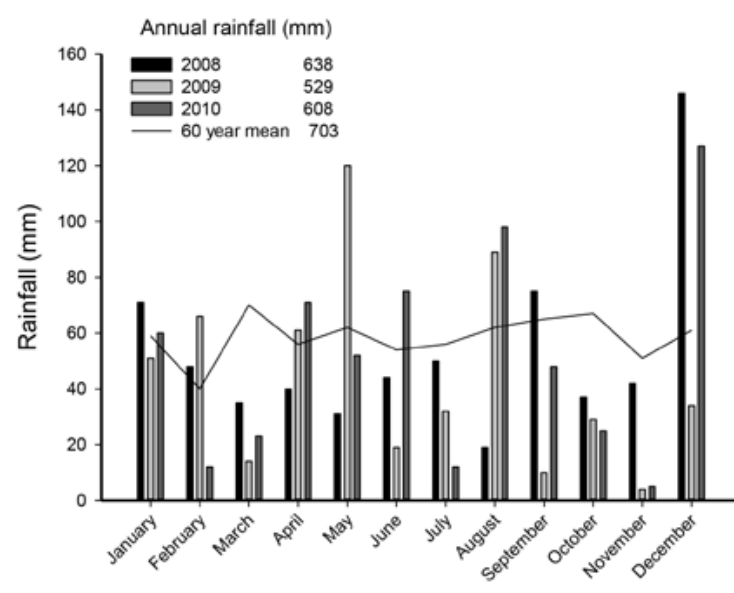

Month

Figure 1 Annual and monthly rainfall during the study period of 2008 to 2010 at the mid-altitude $(700 \mathrm{~m}$ a.s.l.) high country field site on Mt Grand Station, Lake Hawea, Central Otago, New Zealand. NB: autumn (March-May), winter (June-August), spring (September-November), and summer (December-February).

5.5, Olsen $\mathrm{P}$ was $18 \mathrm{mg} / \mathrm{litre}$, and sulphate-S was 9 $\mathrm{mg} / \mathrm{kg}$. The site chosen was representative of the hill block's vegetation cover. Established populations of NAC species and white and sub clover were present among an array of annual and perennial grass species (Table 1) and patches of sweet briar (Rosa rubiginosa L.), matagouri (Discaria toumatou Raoul) and kanuka (Kunzea ericoides J. Thompson) shrubs. During the study period from October 2008 to May 2010, average winter temperatures were $4.2^{\circ} \mathrm{C}$ (day) and $2.7^{\circ} \mathrm{C}$ (night) with a minimum average of $1.5^{\circ} \mathrm{C}$ in June. Average summer temperatures were $15.1^{\circ} \mathrm{C}$ (day) and $11.7^{\circ} \mathrm{C}$ (night) with a maximum average of $15.5^{\circ} \mathrm{C}$ in February. Average annual rainfall (60 years) is $703 \mathrm{~mm}$, with high annual and monthly variability. Annual rainfall collected for 2008 was $638 \mathrm{~mm}$ and for 2009 was 529 $\mathrm{mm}$ (Figure 1).

The hill block was continuously grazed with 300 pregnant Merino ewes (lambing in late September) from the start of spring growth until late summer (February). Grazing resumed again from mid-autumn (April) with 300 ewes and 4 rams and some rising twoyear-old cattle to assist with control of pasture quality by grazing down areas of accumulated standing dead matter. Grazing ceased in mid-winter (July), resuming again in spring. The annual grazing management regime was typical of very low intensity grazing land use.

\section{Experimental Design and Treatments}

This experiment was part of a larger field trial investigating the effect of grazing deferment and superphosphate application on NAC species (Maxwell et al. unpublished). It was established as a factorial split plot randomised complete block design, with two superphosphate $(\mathrm{SP})$ treatment split plots $(2.5 \times 5 \mathrm{~m})$ within grazing management treatment main plots $(5 \times 5$ $\mathrm{m})$ in four blocks. Split plots had either low $(75 \mathrm{~kg} / \mathrm{ha})$ or high $(200 \mathrm{~kg} / \mathrm{ha}$ ) rates of $30 \%$ sulphur SP; the low SP treatment being $5 \mathrm{~kg} \mathrm{P} / \mathrm{ha}$ and $23 \mathrm{~kg} \mathrm{~S} / \mathrm{ha}$ equivalent and the high SP treatment being $9 \mathrm{~kg} \mathrm{P} / \mathrm{ha}$ and $38 \mathrm{~kg}$ $\mathrm{S} /$ ha equivalent. Fertiliser was applied on 6 September 2008.

\section{Measurements}

Two $0.2 \mathrm{~m}^{2}$ quadrat cuts of standing pasture biomass were harvested within split plots in spring, summer, and autumn over a 19-month period from October 2008 to May 2010. Botanical composition was determined by sorting cut herbage to obtain DM values (percentage and $\mathrm{kg} \mathrm{DM} / \mathrm{ha}$ ) of each clover species, grass, weed, herb, and dead matter components at each harvest time. Sorted samples were oven-dried at $70^{\circ} \mathrm{C}$ for 48 hours and weighed.

Seedling recruitment was measured in autumn 2009 and 2010 by counting clover seedling numbers present in 20 soil cores $6.1 \mathrm{~cm}$ diameter by $4.5 \mathrm{~cm}$ deep from each split plot. All clover seedlings present were counted as an estimate of autumn regeneration of clover species per $\mathrm{m}^{2}$.

\section{Statistical analysis}

Data for standing biomass of clover species, grass, weed, herb, and dead matter were analysed using one-way analysis of variance (ANOVA) to determine any statistically significant differences between these botanical components in the first and second year. Superphosphate effect on clover seedling recruitment was analysed by a split plot ANOVA for one date in each year (i.e. autumn 2009 and autumn 2010). All analyses were conducted using GenStat 13 (Lawes Agricultural Trust, Rothamsted, UK).

\section{Results}

Naturalised annual clover species collectively contributed more to pasture biomass than white and sub clovers in both years (Table 1, Figure 2). First year pasture biomass ranged between 1673 and 3582 $\mathrm{kg} \mathrm{DM} /$ ha from October 2008 to May 2009, averaging $2500 \mathrm{~kg} \mathrm{DM} / \mathrm{ha}$. The DM of naturalised annual clover species accounted for $28 \%$, while white and sub clover accounted for only $0.8 \%$ (Table 1 ). The legume content of the pasture varied immensely between years. In the second year, pasture biomass ranged between 1474 and $3523 \mathrm{~kg} \mathrm{DM} / \mathrm{ha}$ from November 2009 to May 2010, averaging $2400 \mathrm{~kg} \mathrm{DM} / \mathrm{ha}$, with NAC species accounting for $2 \%$ and white and sub clover 


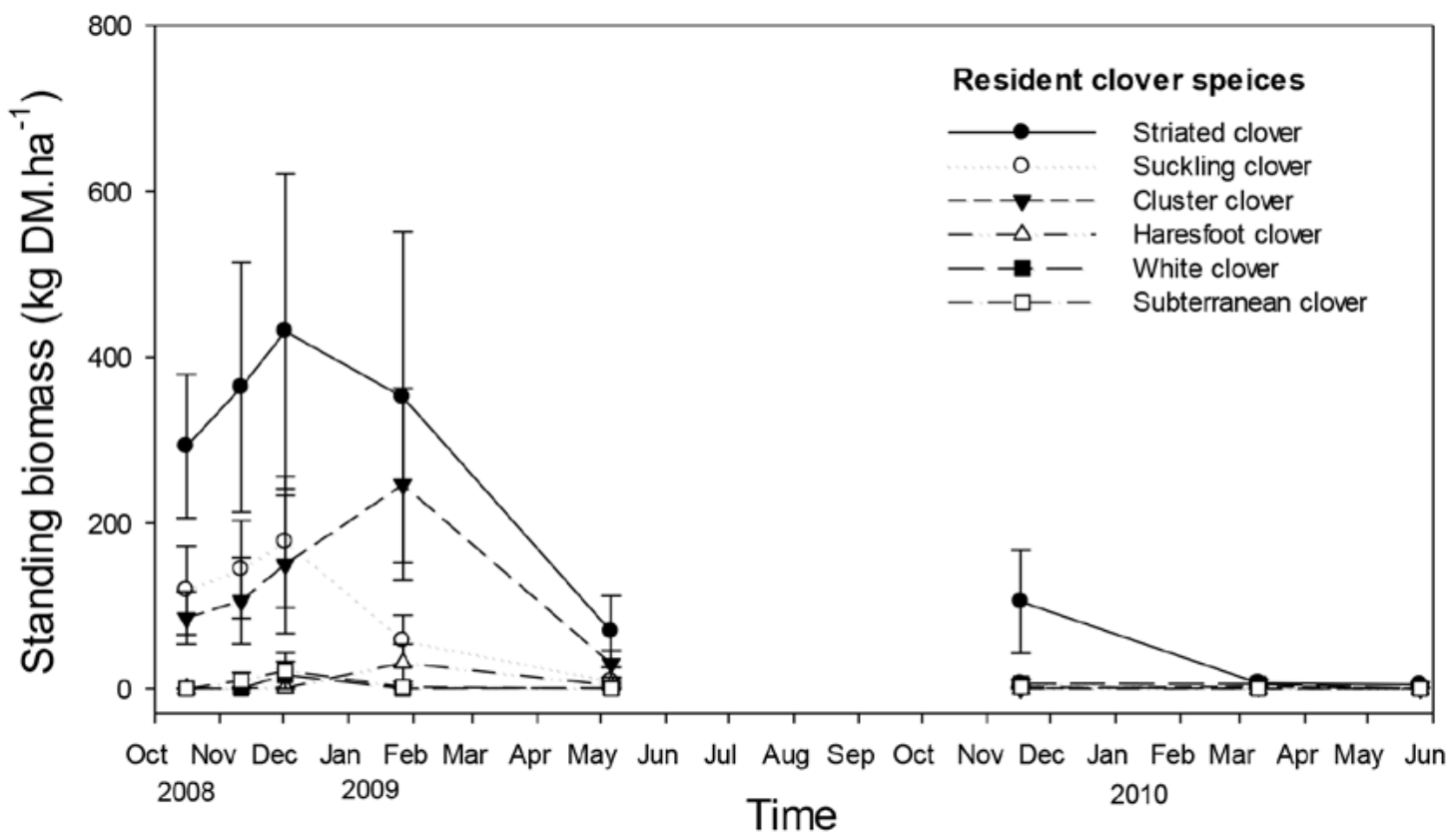

Figure 2 Standing biomass ( $\mathrm{kg} \mathrm{DM} / \mathrm{ha}$ ) of all naturalised annual clover species (striated clover Trifolium striatum, suckling clover T. dubium, cluster clover T. glomeratum, haresfoot clover T. arvense) and white clover T. repens and subterranean clover T. subterraneum from October 2008 to May 2010 in a summer dry, mid-altitude (680-700 m a.s.l.), north-facing (sunny) upland pasture community on Mt Grand Station, Central Otago, New Zealand. Error bars are \pm SEM.

accounted for $0.2 \%$ (Table 1). Clover standing biomass (naturalised species and white and sub clover) averaged $689 \mathrm{~kg} \mathrm{DM} / \mathrm{ha}$ in the first year, falling considerably to $58 \mathrm{~kg} \mathrm{DM} /$ ha in the second year (Table 1), strongly reflecting the general scarcity of clover during midspring of the second year (Figure 2).

Striated clover was the dominant species with more standing biomass $(\mathrm{P}<0.001)$ than all other clover species in both years (Table 1). Striated clover contributed 343 $\mathrm{kg} \mathrm{DM} / \mathrm{ha}(14 \%)$ in the first year, while cluster clover contributed $187 \mathrm{~kg} \mathrm{DM} / \mathrm{ha}(7.2 \%)$, and suckling clover $126 \mathrm{~kg} \mathrm{DM} / \mathrm{ha}(5.7 \%)$ to first year total pasture biomass (Table 1). Haresfoot, white, and sub clovers were least dominant with less standing biomass $(\mathrm{P}<0.001)$ than striated, cluster, and suckling clovers (Table 1 and Figure 2). In the second year, striated clover standing biomass dropped to $47 \mathrm{~kg} \mathrm{DM} / \mathrm{ha}(1.7 \%)$ with the standing biomass of cluster, suckling, haresfoot, white and subterranean clovers not significantly different from each other $(\mathrm{P}<0.001$, Table 1 and Figure 2).

\section{Superphosphate}

Superphosphate application influenced clover regeneration, with more seedlings observed under low SP application. In May 2010, average clover seedling recruitment was significantly greater $(\mathrm{P}<0.001)$ in low SP split plots (563 seedlings $/ \mathrm{m}^{2}$ ) than high SP split plots (271 seedlings $\left./ \mathrm{m}^{2}\right)$. A significant interaction $(\mathrm{P}<0.001)$ between clover species and SP was observed in May 2010 (Figure 3). Striated, suckling and cluster clovers showed greater seedling recruitment under low SP fertiliser application with 1406, 1559 and 365 seedlings/ $\mathrm{m}^{2}$ respectively, compared to 756,637 and 176 seedlings/ $\mathrm{m}^{2}$ respectively within the high SP treatment (Figure 3).

\section{Discussion}

\section{Naturalised clover dominance}

Three NAC species (striated, cluster and suckling clover) produced more DM over two growing seasons and regenerated with larger seedling populations in consecutive autumns than white and sub clover at this site. These NAC species have the ability to grow to maturity and produce viable seed in most years before the onset of late spring-summer soil moisture deficits, followed by autumn regeneration every year from the large soil seed reserve. White and sub clover were not dominant at any time over the 19-month period, adding further support to the contention that white clover (Knowles et al. 2003) and sub clover (Power et al. 2006) struggle to persist and make a valuable contribution to summer dry hill pastures of north-facing aspect.

This observed NAC species abundance is attributed to their ability to germinate and establish seedlings at lower temperatures than white clover in autumn. They have lower base temperatures for germination and lower thermal time requirements for seedling emergence and 


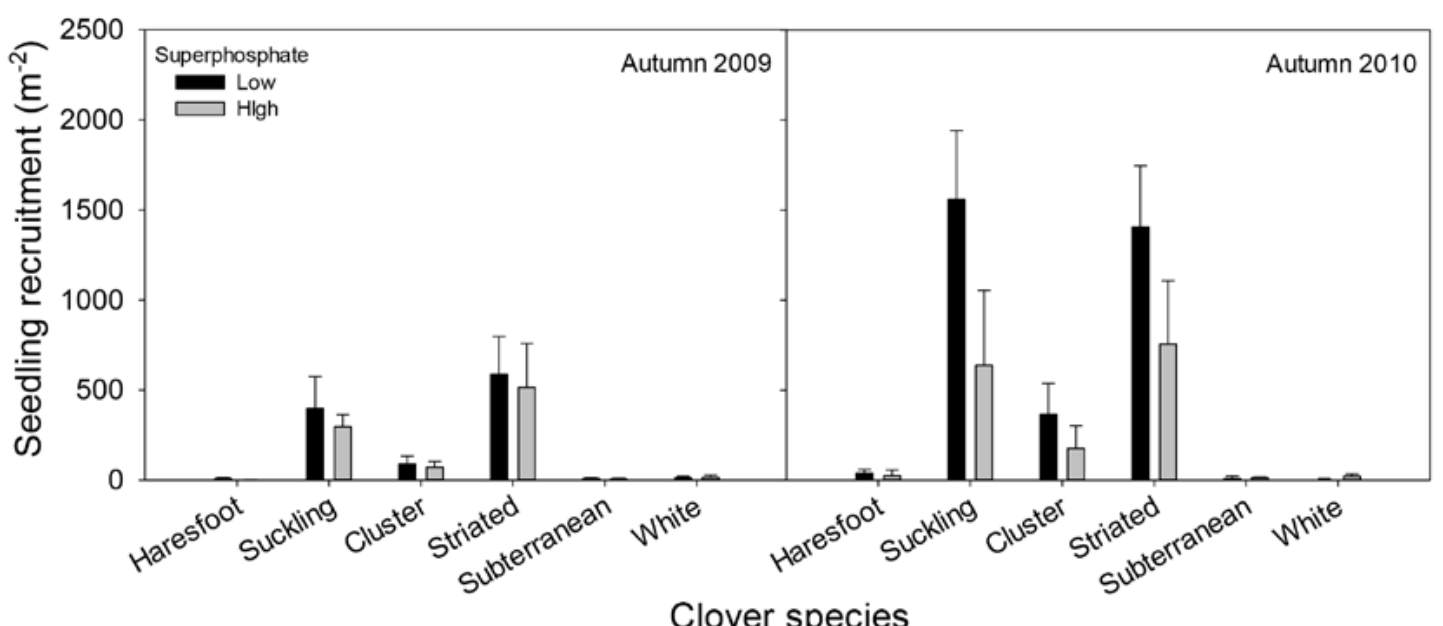

Figure 3 Influence of low $(75 \mathrm{~kg} / \mathrm{ha})$ and high $(200 \mathrm{~kg} / \mathrm{ha})$ superphosphate fertiliser application (30\% sulphur super) on seedling recruitment $\left(\mathrm{m}^{2}\right)$ of the six resident clover species over two consecutive autumns in a summer dry, mid-altitude (680-700 $m$ a.s.I.), north-facing (sunny) upland pasture community on Mt Grand Station, Central Otago, New Zealand. Error bars are \pm SEM

seedling growth than white clover (Lonati et al. 2009). Striated, cluster and suckling clovers are well adapted to regenerating and producing biomass under the climatic conditions of north-facing slopes on Mt Grand Station. As annual plants, they can complete their lifecycle (germinate, establish, flower, and produce seed) before the onset of soil moisture deficits typical of sunnier northern aspects in late spring-summer (Lambert \& Roberts 1976) that are detrimental to white clover growth and stolon propagation in most years.

\section{Seasonal rainfall influence}

Large variation in annual clover abundance was strongly driven by contrasting rainfall received during the spring and early summer periods in 2008 and 2009. Naturalised annual clover species average biomass was approximately 14 times greater in the first year (2008/2009 season) than the second year (2009/2010 season). Rainfall during the growing season in September, October, November and December 2008 was much greater at $75,37,42$ and $146 \mathrm{~mm}$ respectively than that of the following year (2009) at 10,29, 4 and $34 \mathrm{~mm}$, respectively. This was particularly evident in September and November of 2009 when rainfall was considerably lower than the 60 year average for those months in spring.

Hepp et al. (2003) attributed a 2.5-fold difference in clover abundance (white, subterranean, suckling and cluster clovers) to higher soil moisture availability and more even rainfall distribution in the second season in comparison to the first season of sampling in summer dry North Island east coast hill country. Though soil moisture levels were not measured at our site, we can assume spring and early summer soil moisture availability for dominant NAC species was greater during the first year growing season.

Despite the large variation in clover content, average pasture biomass was similar (2433 and $2500 \mathrm{~kg} \mathrm{DM} /$ ha) between the two years owing to the large mass of dead material accumulation during the first year that remained for much of the second year. These values are comparable to other South Island hill country (200-600 $\mathrm{m}$ a.s.l.) annual pasture biomass values recorded in low rainfall areas (350-760 mm), (White et al. 1972; Radcliffe \& Cossens 1974; Vartha et al. 1982) as well as summer dry $(800 \mathrm{~mm})$ North Island hill country annual pasture biomass (Gillingham et al. 1998).

\section{Superphosphate response}

Prior to fertiliser application at this field site, available $\mathrm{P}$ was moderate while available $\mathrm{S}$ was low. Significantly more striated, suckling and cluster clover seedlings were evident in low SP spilt plots. These clover species appear to have a low $\mathrm{S}$ requirement for optimum DM production (Maxwell et al. 2012) with adaptation to low soil P levels (Dodd \& Orr 1995).

Within the lower-middle altitude zone of Mt Grand, no association was observed between soil S fertility level and botanical cover (percent) of striated, cluster, and suckling clover (Maxwell et al. 2010). Maxwell et al. (2012) concluded that all four NAC species require low $\mathrm{S}$ availability for optimum DM production, under conditions of optimum soil $\mathrm{pH}, \mathrm{P}$ fertility, and micronutrient status. Beale et al. (1993) reported striated clover being associated with soils of very low P status in Morocco. Similarly, Maxwell et al. (2010) found 
greater striated clover percent cover was associated with lower soil P levels in the lower-middle altitude range at Mt Grand. Maxwell et al. (2013) reported all four NAC species showed optimum DM accumulation under low to medium soil P fertility, with striated clover showing a relative lower DM response to increasing $\mathrm{P}$ fertility in a South Island high country soil compared to suckling, cluster and haresfoot clovers.

\section{Conclusion}

Three NAC species (striated, cluster, and suckling clover) contributed more to pasture biomass than traditionally sown species of white and sub clover at a sunny-aspect, summer dry hill environment during a moist year. In a very dry year, NAC species abundance dropped, though striated clover still outperformed white and sub clover, with the other NAC species having similar biomass to white and sub clover. The contributions of NAC species appear extremely significant for annual biomass provision to grazing livestock and $\mathrm{N}$ inputs in the climatically-variable hill and high country zone.

Spreading NAC species within grazed hill and high country areas should be strongly encouraged to increase pasture legume content for livestock feed in spring and associated annual N-fixation inputs. Spreading NAC species could be achieved through concentrated grazing pressure in areas where NAC species are abundant and subsequent seed dispersal via dung to exploit soil moisture in favourable rainfall years for annual legume production. Aerial broadcasting of NAC seed will further their spread to areas in hill and high country of limited legume cover and introduce these species to areas where they have yet to arrive and colonise.

Phosphorus and sulphur requirements of NAC species appear to be low. If increasing NAC species abundance is the focus, adjustment to traditional applications of superphosphate could be considered. This is important as heavy superphosphate application has traditionally been the pathway of intensification in South Island hill and high country.

\section{ACKNOWLEDGEMENTS}

Research funding provided by the Miss E.L. Hellaby Indigenous Grasslands Research Trust. Thanks to Evan Gibson, Keith Pollock, Daniel Dash, Elina Stang, Steele Taylor, Marianna Gallo, Vonny Fasi, Rob Kidd and Kimberley Pulley for valuable field assistance at Mt Grand.

\section{REFERENCES}

Bowatte, S.; Russell, T.; Carran, A.; Gillingham, A.G. 2006. Can phosphorus fertilizers alone increase levels of soil nitrogen in New Zealand hill country pastures? Nutrient Cycling in Agroecosystems 75: 57-66.
Boswell, C.C.; Lucas, R.J.; Lonati, M.; Fletcher, A.; Moot, D.J. 2003. The ecology of four annual clovers adventive in New Zealand grasslands. Legumes for dryland pastures. Proceedings of the New Zealand Grassland Association Symposium, Grassland Research and Practice Series 11: 175-188.

Beale, P.E.; Bounejmate, M.; Lahlou, A.; Marx, D.B.; Christiansen, S.; 1993. Distribution of annual Trifolium species in Morocco. Australian Journal of Agricultural Research 44: 1303-1310.

Dodd, M.D.; Orr, S.J. 1995. Seasonal growth, flowering patterns, and phosphate response of 18 annual legumes grown in a hill country soil. New Zealand Journal of Agricultural Research 38: 21-32.

Duncan, R.; Lucas, R.J.; Palmer, C. 1997. Mt Grand Station: Baseline survey of the vegetation and soils. Department of Plant Science, Lincoln University, Canterbury, New Zealand. 40 pp.

Edmeades, D.C.; Feyter, C.; O’Connor, M.B. 1984. Lime and phosphorus requirements for hill country yellow-brown earths. Proceedings of the New Zealand Grassland Association 45: 98-106.

Moot, D.J.; Mills, A.M.; Lucas, R.J.; Scott, W.R. 2009. FAO Country Pasture/Forage Resource Profiles, New Zealand. Food and Agriculture Organisation of the United Nations. Accessed January 15th 2012 http://www.fao.org/ag/AGP/AGPC/doc/Counprof/ newzealand/newzealand2.htm.

Gillespie, B.J.; Lucas, R.J.; Moot, D.J.; Edwards, G.R. 2006. Can topdressing with salt increase oversowing success and pasture quality on steep, south facing slopes in hill country pastures. Proceedings of the New Zealand Grassland Association 68: 349-353.

Gillingham, A.G.; Gray, M.H.; Smith, M.R. 1998. Pasture responses to phosphorus and nitrogen fertilizers on dry hill country. Proceedings of the New Zealand Grassland Association 60: 135-140.

Haynes, R.J.; Williams, P.H. 1993. Nutrient cycling and soil fertility in the grazed pasture ecosystem. Advances in Agronomy 49: 119-199.

Hepp, C.; Valentine, I.; Hodgson, J.; Gillingham, A.G.; Kemp, P.D. 2003. Effects of grass suppression on legume abundance during two contrasting seasons on a summer-dry hill country site. Legumes for Dryland Pastures. Grassland Research and Practice Series 11: 123-129.

Knowles, I.M.; Fraser, T.J.; Daly, M.J. 2003. White clover: loss in drought and subsequent recovery. Legumes for dryland pastures. Proceedings of New Zealand Grassland Association symposium, Grassland Research and Practice Series 11: 37-42.

Lambert, M.G.; Roberts, E. 1976. Aspect differences in an unimproved hill country pasture. 1. Climatic differences. New Zealand Journal of Agricultural Research 19: 459-467. 
Lonati, M.; Moot, D.J.; Aceto, P.; Cavallero, A.; Lucas, R.J. 2009. Thermal time requirements for germination, emergence and seedling development of adventive legume and grass species. New Zealand Journal of Agricultural Research 52: 17-29.

Maxwell, T.M.R.; Moir, J.L.; Edwards, G.R. 2010. Influence of environmental factors on the abundance of naturalized annual clovers in the South Island hill and high country. Proceedings of the New Zealand Grassland Association 72: 165-170.

Maxwell, T.M.R.; Moir, J.L.; Edwards, G.R. 2012. Sulphur and lime response of four adventive annual clover species grown in a New Zealand high country soil under glasshouse conditions. New Zealand Journal of Agricultural Research 55: 47-62.

Maxwell, T.M.R.; Moir, J.L.; Edwards, G.R. 2013. Phosphorus response and efficiency of four adventive annual clover species grown in a New Zealand high country soil under glasshouse conditions. New Zealand Journal of Agricultural Research 56: 203214.

Moir, J.L.; Hedley, M.J.; Mackay, A.D.; Tillman, R.W. 1997. The effect of fertilizer history on nutrient accumulation and plant-available nutrient supply in legume-based pasture soils. Proceedings of the XVIII International Grassland Congress, Winnipeg, Canada. pp. 10, 68-69.

Moir, J.L.; Moot, D.J. 2010. Soil pH, exchangeable aluminum and lucerne responses to lime in a South Island high country soil. Proceedings of the New Zealand Grassland Association 72: 191-195.

O’Connor, K. 2003. Conflicting innovations: a problem for sustainable development of New Zealand high country grasslands. Mountain Research and Development 23: 104-109.
Power, D.R.; Pollock, K.M.; Lucas, R.J.; Moot, D.J. 2006. Clover species on summer dry hill country in Central Otago. Proceedings of the New Zealand Grassland Association 68: 343-347.

Radcliffe, J.E.; Cossens, G.G. 1974. Seasonal distribution of pasture production in New Zealand. III. Central Otago. New Zealand Journal of Experimental Agriculture 2: 349-358.

Rose, A.B.; Frampton. C.M. 2007. Rapid shorttussock grassland decline with and without grazing, Marlborough, New Zealand. New Zealand Journal of Ecology 31: 232-243.

Vartha, E.W.; Archie, W.J.; Archer, A.C.; Hoglund, J.H. 1982. Management of grassland on sunny aspect of North Canterbury dry hill country: environment and quantity and quality of herbage. New Zealand Journal of Agricultural Research 25: 475-483.

Webb, C.J.; Sykes, W.R.; Garnock-Jones, P.J. 1988. Flora of New Zealand Volume IV. Naturalized pteridophytes, gymnosperms, dicotyledons. Botany Division. Department of Scientific and Industrial Research, Christchurch, New Zealand. 1365 pp.

White, J.G.H. 1990. Hill and high country pasture. pp. 299-336. In: Pastures; their ecology and management. Ed. Langer, R.H.M. Oxford University Press, Auckland.

White, J.G.H.; Meijer, G.; Langer, R.H.M. 1972. Over sowing grasses on sunny and shady faces. Proceedings of the New Zealand Grassland Association 34: 139-146. 